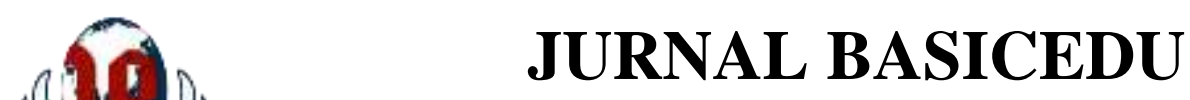

Volume 5 Nomor 6 Tahun 2021 Halaman 5436 - 5444

Research \& Learning in Elementary Education https://jbasic.org/index.php/basicedu

\title{
Pengembangan Konten E-Learning Motion Graphic dan Website Wordpress pada Pembelajaran Warga di Sekolah Dasar
}

\section{Otib Satibi Hidayat}

Pendidikan Guru Sekolah Dasar, Universitas Negeri Jakarta, Indonesia

E-mail: otibsatibi@unj.ac.id

\begin{abstract}
Abstrak
Penelitian ini bertujuan untuk menghasilkan konten E-Learning motion grafhic dan website worpress pada pembelajaran PPKn di Kelas V Sekolah Dasar. Metode penelitian yang digunakan adalah model ADDIE yaitu: Analyze, Design, Development, Implementation, and Evaluation. Hasil penelitian menunjukkan bahwa konten e-learning dikatakan layak oleh ahli materi, bahasa, dan media, dalam mengembangkan website ini yang dibantu dengan CMS yaitu wordpress yang akan memudahkan peneliti dalam membangun website lebih menarik, serta penggunaan plugin untuk membantu membangun website. hasil validasi ahli materi, ahli media, dan ahli bahasa, dapat diketahui hasil validasi ahli materi sebesar 94\% atau sangat baik, ahli media 97,3\% atau sangat baik, dan ahli bahasa 87,5\% atau sangat baik. Sedangkan hasil uji coba One to One didapatkan hasil 96\% atau sangat baik. Konten E-learning ini dapat dijadikan alternatif dalam pembelajaran secara online khususnya pada materi PPKn di sekolah dasar sesuai kondisi masa pandemic COVID-19.
\end{abstract}

Kata Kunci: konten e-learning, motion graphic, website, Wordpress, PPKN.

Abstract

This study aims to produce motion graphic E-Learning content and website WordPress in Civics learning in Class V Elementary School. The research method used is the ADDIE model, namely: Analyze, Design, Development, Implementation, and Evaluation. The results of the study indicate that e-learning content is considered feasible by material, language, and media experts, in developing this website assisted by a CMS, namely WordPress which will facilitate researchers in building more attractive websites, as well as using plugins to help build websites. the results of the validation of material experts, media experts, and linguists, it can be seen that the validation results of material experts are $94 \%$ or very good, media experts are $97.3 \%$ or very good, and linguists are $87.5 \%$ or very good. While the results of the One to One trial obtained $96 \%$ or very good results. This E-learning content can be used as an alternative in online learning, especially on Civics material in elementary schools according to the conditions during the COVID-19 pandemic.

Keywords: e-learning content, motion graphics, websites, Wordpress, PPKn.

Copyright (c) 2021 Otib Satibi Hidayat

Corresponding author :

Email : otibsatibi@unj.ac.id

DOI $\quad$ : https://doi.org/10.31004/basicedu.v5i6.1668

ISSN 2580-3735 (Media Cetak)

ISSN 2580-1147 (Media Online) 
5437 Pengembangan Konten E-Learning Motion Graphic dan Website Wordpress pada Pembelajaran Warga di Sekolah Dasar - Otib Satibi Hidayat

DOI: https://doi.org/10.31004/basicedu.v5i6.1668

\section{PENDAHULUAN}

Pendidikan adalah sasaran utama bagi suatu negara untuk meningkatkan sumber daya manusia dalam mengikuti perkembangan dunia. Oleh sebab itu, kualitas sumber daya manusia perlu ditingkatkan karena peningkatan kualitas sumber daya manusia merupakan syarat utama untuk mencapai tujuan pembangunan. Peningkatan sumber daya manusia dilakukan secara seksama dan terencana berdasarkan kepentingan kemajuan ilmu pengetahuan yang berlandasakan pada keimanan dan ketakwaan kepada Tuhan Yang Maha Esa.

Sekolah dirasa mampu memenuhi kebutuhan siswa salah satunya dengan perkembangan teknologi dari berbagai media yang ada. Perkembangan teknologi di zaman sekarang ini memberikan banyak kemudahan bagi setiap individu dalam melakukan berbagai aktivitasnya, tidak terkecuali dalam dunia pendidikan. Teknologi sangat lah berperan penting dalam dunia pendidikan. Salah satu perkembangan teknologi yang sedang berkembang pesat adalah internet, internet yaitu kumpulan dari jutaan komputer yang digunakan untuk mendapatkan segala bentuk informasi baik mengirim maupun menerima dari komputer lain yang ada di dalam kumpulan tersebut. Usaha-usaha yang dilakukan untuk meningkatkan kualitas pendidikan selalu dilakukan, termasuk bagaimana cara mengajar yang efektif dan efisien dengan menggunakan teknologi (Das et al., 2016; Wu \& Tai, 2016).

Apalagi saat ini sedang terjadi pandemi virus Covid-19 yang telah membawa perubahan besar terhadap semua kegiatan, baik dari pekerjaaan, kesehatan, gaya hidup dan juga pendidikan. Pembelajaran secara daring telah dianjurkan pemerintah saat ini (Bhamani et al., 2020; Dhawan, 2020; Mahyoob, 2020). Namun, pembelajaran daring ternyata hanya dominan dalam pemberian tugas bukan fokus kepada proses transfer ilmu pengetahuan dan pengembangan karakter, serta penggunaan media pembelajaran biasanya hanya terpaku pada buku kurikulum 2013. Aktivitas inilah yang menjadi kesenjangan antara pendidikan yang ada dengan tujuan pendidikan nasional dimana mampu mengembangkan pribadi siswa menjadi lebih baik, terampil, dna bermoral (Dhawan, 2020; Fahrurrozi et al., 2020; Widodo et al., 2020).

Dalam pembelajaran PPKn juga ditemui kesulitan dalam proses transfer ilmu pengetahuan dan pengembangan sikapnya, karena pembelajaran PPKn membutuhkan hasil berupa sikap yang dapat diimplementasikan dalam kehidupan sehari-hari dan tampaknya sulit jika dilakukan pengajaran secara daring.

Saat proses transfer ilmu pengetahuan yang didominasi oleh tugas-tugas dan belum bisa memantau sikap siswa dalam implementasinya, dapat disebabkan karena pendidik masih belum mengetahui cara yang baik dalam menjelaskan pembelajaran seperti saat dikelas dengan menggunakan buku-buku dan benda nyata atau dengan metode pembelajaran yang bervariasi yang biasa digunakan oleh guru. (Sadikin et al., n.d. 2020) Pendidikan Kewarganegaraan memegang peran yang amat sentral dalam meningkatkan kompetensi kewarganegaraan siswa, yaitu: pengetahuan, kecakapan dan watak (Pangalila, 2017). Pembelajaran PPKn yang terkesan membosankan akan menambah peserta didik malas belajar dan cepat bosan. Di samping itu pada pembelajaran PPKn terdapat materi-materi yang sulit dijelaskan jika hanya berupa verbalisme. Tentunya membutuhkan suatu media yang mampu memudahkan siswa memhami materi pelajaran.

Untuk menunjang hal tersebut peneliti tertarik untuk menyelesaikan permasalahan yang ada yaitu dengan adanya pengembangan konten e-learning. E-learning merupakan pembelajaran yang melibatkan penggunaan peralatan elektronik dalam memudahkan suatu proses belajar mengajar di mana siswa sebagai pusatnya serta dilakukan secara interaktif kapanpun dan di manapun (Karwati, n.d. 2014). E-learning yang akan dikembangkan yaitu berbasis motion graphic dan website wordpress, pengembangan ini juga dapat digunakan untuk blended learning. Motion graphic merupakan cabang ilmu desain grafis yang menggunakan video atau animasi secara sengaja digerakkan atau diberi penggerakan (Saputra, 2018) dan Website adalah kumpulan-kumpulan dari halaman sebuah situs, yang biasanya terangkum dalam sebuah domain atau pun sub domain, yang tempatnya berada dalam World Wibe Web (WWW) di dalam internet (Trimarsiah \& Arafat, 
5438 Pengembangan Konten E-Learning Motion Graphic dan Website Wordpress pada Pembelajaran Warga di Sekolah Dasar - Otib Satibi Hidayat

DOI: https://doi.org/10.31004/basicedu.v5i6.1668

2017). Penelitian (Djamas et al., 2018; Makhaya \& Ogange, 2019; Mocanu \& Schipor, 2017; Segeč, 2015) menyatakan bahwa pembelajaran yang menggunakan teknologi dapat memfasilitasi siswa dalam memahami materi khususnya pada materi yang bersifat abstrak. Pembelajaran model ini dapat berbentuk elearning, pembelajaran digital, dan pembelajaran campuran (blended learning).

Dengan banyaknya fitur yang disediakan oleh produk ini dan isi dari pelajaran yang diubah seperti mengubah teks-teks yang ada di buku menjadi video penjelasan guru, latihan soal yang menarik dengan quizizz, permainan, dan forum diskusi. Dari aplikasi quizizz ini peneliti menggunakannya sebagai salah satu bentuk evaluasi tes formatif yang dibuat dengan sedemikian kreatif yaitu dengan memunculkan banyak gambar di setiap pertanyaannya agar siswa dapat menjawabnya tanpa harus terlalu banyak membaca.

Selain itu terdapat menu permainan, video, materi, soal, forum diskusi bersama, dan yang unik adalah komik online yang dapat diakses di dalam satu website. Penulis sengaja menyisipkan menu permainan dan komik online adalah agar peserta didik tidak terlalu cepat bosan jika berlama-lama di dalam website. Oleh karena itu, pembelajaran perlu dikembangkan dengan bantuan dari media pembelajaran yang interaktif juga, karena dengan mengembangkan konten website yang bervariatif akan menambah semangat belajar siswa, lebih memotivasi siswa untuk mendalami pembelajarannya yang akan berakibat pada kenaikan hasil belajar siswa, ini juga dapat melatih kemandirian belajar anak. Jadi, pengembangan konten e-learning berbasis motion graphic dan website wordpress dapat menjadi jawaban yang tepat dari permasalahan yang telah dijabarkan di atas. Wordpress adalah aplikasi CMS (Content Management System) yang dapat berfungsi untuk memudahkan membuat post, halaman statis, menu, dan lainnya tanpa perlu bersusah payah mempelajari bahasa pemrograman yang sulit. (Adindda Qori Aini dan Joni Dwi Pribadi, 2017).

Kebaruan dalam penelitian ini membuat produk pengembangan yang dikembangkan peneliti konten $e$ learning (motion graphics dan website wordpress) untuk pembelajaran PPKn SD di Kelas V Sekolah Dasar dengan tema "Sehat Itu Penting" Media ini dinamakan konten e-learning (motion graphics dan website wordpress) karena pembuatan media ini memanfaatkan program Wordpress dan pemakaian pembuatan video dengan fitur materi pembelajaran, kuis, games video, komik, forum diskusi, penguatan karakter, dan pengumpulan tugas di dalam satu website konten e-learning ini berisi tentang hak, kewajiban, dan tanggung jawab khusus materi kelas V SD.

Saat ini sudah banyak media pembelajaran yang dikembangan menggunakan teknologi dengan menggunakan teknik Motion Graphic, Asih Purwasih (2015), dalam penelitiannya menjelaskan motion graphic pembelajaran yang dikembangkan efektif dan dapat melatih keterampilan berpikir kritis siswa. Sementara Satria Rusdiansyah, (2020) menjelaskan pembelajaran Motion Graphic matematika berbasis Android ini layak digunakan dalam pembelajaran. Pengembangan dan implementasi blended learning serta meningkatkan dukungan fasilitas dan akses terhadap internet yang memadai, (Maudiarti, 2018; Modlinger, 2020).

Melalui pengembangan media pembelajaran motion graphic dan website wordpress ini peneliti bertujuan untuk membuat peserta didik akan lebih semangat lagi untuk belajar PPKn Kelas V Sekolah Dasar. Video pembelajaran yang dikemas dalam bentuk aplikasi, peserta didik dapat belajar dimana saja dan kapan saja. Pembelajaran juga lebih menyenangkan karena adanya visualisasi secara nyata dibandingkan dengan hanya membaca buku dan ceramah guru yang dapat membuat siswa merasa bosan. Dengan demikian, diharapkan pembelajaran matematika akan lebih menarik perhatian siswa terhadap pelajaran PPKn sehingga tujuan pembelajaran matematika akan tercapai secara optimal.

\section{METODE}

Metode penelitian yang digunakan dalam penelitian ini adalah Penelitian dan Pengembangan yang dalam Bahasa Inggris disebut Research and Development (R\&D). Research and development $(\mathrm{R} \& \mathrm{D})$ adalah 
5439 Pengembangan Konten E-Learning Motion Graphic dan Website Wordpress pada Pembelajaran Warga di Sekolah Dasar - Otib Satibi Hidayat

DOI: https://doi.org/10.31004/basicedu.v5i6.1668

metode penelitian yang digunakan untuk menghasilkan produk tertentu, dan menguji keefektifan produk tersebut (Sugiyono, 2013). Penelitian dan pengembangan merupakan proses atau langkah-langkah untuk menyempurnakan suatu produk baru dan dapat diuji keefektifannya sebelum produk tersebut diproduksi masal agar produk tersebut menjadi sebuah produk yang tepat sasaran dan efektif bagi penggunaannya.

ADDIE merupakan akronim dari beberapa tahapan yaitu Analysis, Pada tahap ini berupa analisis tujuan, kurikulum dan materi, tingkat kemampuan dan karakteristik sasaran penggunaan. Yang kedua tahap Design, Dalan tahap ini berupa perancangan butir-butir materi yang akan disajikan, penyusunan naskah materi, penyusunan alur penyampaian materi dalam bentuk flowchart, pembuatan storyboard media, dan pengumpulan bahan-bahan yang dibutuhkan dalam pengembangan media. Selanjutnya tahap Develop, pada tahap ini adalah proses mengembangkan media pembelajaran dalam hal ini mengembangkan media pembelajaran Motion Graphic dan wordpress berdasarkan rancangan pada tahap design yang telah dilakukan sebelumnya. Yang keempat tahap Implement, pada tahap ini media pembelajaran yang telah selesai dibuat dan diuji cobakan kepada beberapa ahli yang terdiri dari ahli materi dan ahli media serta di uji coba kepada peserta didik kelas V Sekolah Dasar untuk mengetahui respon dari pengguna. Yang terakhir tahap Evaluate, pada tahap ini Revisi produk dilakukan, apabila ada masukan dari para ahli. Peneliti selalu mengevaluasi kinerja media pembelajaran Motion Graphic dan wordpress untuk mengetahui kelemahan-kelemahan yang ada.

Teknik pengambilan data yang dipakai adalah observasi, wawancara, dan penyebaran kuesioner. Instrumen pengumpulan data yang Peneliti gunakan adalah kuesioner. Kuesioner dikumpulkan melalui pengujian para ahli (expert review) dan peserta didik kelas V SD dalam tahap uji perorangan (one to one).

\section{HASIL DAN PEMBAHASAN}

Penelitian dilaksanakan pada semester 1 tahun ajaran 2020/2021, pada bulan November 2020 sampai Januari 2021. Pengembangan produk ini dilakukan dengan menggunakan model pengembangan dari ADDIE yang di dalamnya terdiri dari lima tahapan, yaitu; Analysis, Design, Development, Implementation, and Evaluation. Pengembangan produk ini sudah melakukan tahap uji coba dan penilaian dari para ahli dan pengguna (peserta didik kelas V SD). Hasil dari tahap uji coba dan penilaian menunjukkan bahwa produk ini sangat baik saat digunakan

Anggota peneliti dua juga menggunakan ADDIE (Analysis, Design, Development, Implementation, Evaluation) sebagai acuannya, karena ADDIE terlihat sangat cocok dalam pengembangan ini. Pada tahap analysis (analisis) Peneliti melakukan analisis kebutuhan, pada tahap design (desain), peneliti mulai merancang hal-hal yang akan dibutuhkan dalam tahap pembuatan produk, kemudian pada tahap development (pengembangan), peneliti mulai membuat produknya dan melakukan review produk dan uji ahli. Dalam tahap implementation (implementasi), peneliti segera mengimplementasikan produk kepada peserta didik kelas $\mathrm{V}$ SD di sekitar rumah Peneliti, namun hanya sampai pada tahap one to one yang melibatkan tiga orang saja, dikarenakan adanya Pandemi Covid-19. Dan yang terakhir adalah tahap evaluation (evaluasi), Peneliti mulai membahas hasil dari implementasi kepada peserta didik kelas $\mathrm{V}$ dengan kuesioner yang telah diberikan kepada tiga orang.

Berdasarkan langkah-langkah pengembangan metode penelitian, maka hasil yang dicapai adalah sebagai berikut: Konten E-learning (Motion graphics dan Website Wordpress) dalam muatan pelajaran PPKn tema Sehat Itu Penting dengan materi hak, kewajiban, dan tanggung jawab di kelas V sekolah dasar. Konten E-learning yang dikembangkan, dinyatakan layak digunakan berdasarkan validasi oleh ahli materi, validasi ahli bahasa, validasi ahli media, dan hasil uji coba oleh guru serta tanggapan siswa.

Tabel 1 dan 2 berikut adalah penilaian ahli materi berdasarkan instrument yang digunakan pada tahap expert review. 
5440 Pengembangan Konten E-Learning Motion Graphic dan Website Wordpress pada Pembelajaran Warga di Sekolah Dasar - Otib Satibi Hidayat

DOI: https://doi.org/10.31004/basicedu.v5i6.1668

Tabel 1. Hasil Rekapitulasi Ahli Materi Anggota Peneliti Satu

\begin{tabular}{|c|c|}
\hline Aspek & Skor Presentase \\
\hline Keselarasan Kompetensi & $81,25 \%$ \\
\hline Isi Materi & $91,67 \%$ \\
\hline Tingkat Ketertarikan dan Keterlibatan & $75 \%$ \\
\hline Rata-Rata Skor & $83,33 \%$ \\
\hline
\end{tabular}

Tabel 2. Hasil Rekapitulasi Ahli Materi Anggota Peneliti Dua

\begin{tabular}{|c|c|}
\hline Aspek & Skor Presentase \\
\hline Keselarasan Materi & $100 \%$ \\
\hline Isi Materi & $93,3 \%$ \\
\hline Kelayakan Isi & $92 \%$ \\
\hline Rata-Rata Skor & $94 \%$ \\
\hline
\end{tabular}

Berdasarkan tabel 1 di atas, dapat dilihat bahwa produk konten e-learning motion graphics oleh anggota peneliti satu mendapatkan hasil sebesar $83,33 \%$ oleh ahli materi maka dapat dikategorikan sangat baik. Dan pada tabel 2 diatas, dapat dilihat anggota dua mendapat hasil sebesar $94 \%$ oleh ahli materi maka dapat dikategorikan sangat baik. Sedangkan hasil penilaian ahli bahasa tersaji pada tabel 3 dan 4.

Tabel 3. Hasil Rekapitulasi Ahli Bahasa Anggota Peneliti Satu

\begin{tabular}{lc}
\hline \multicolumn{1}{c}{ Aspek } & Skor Presentase \\
\hline Kejelasan Bahasa & $100 \%$ \\
\hline Ekonomis & $100 \%$ \\
\hline Kesatuan \& Organis & $100 \%$ \\
\hline Gaya atau Tipe Huruf & $100 \%$ \\
\hline Tipografi & $100 \%$ \\
\hline Warna $\quad 100 \%$ \\
\hline \multicolumn{1}{c}{ Rata-Rata Skor } & $100 \%$ \\
\hline
\end{tabular}

Tabel 4. Hasil Rekapitulasi Ahli Bahasa Anggota Peneliti Dua

\begin{tabular}{cc}
\hline \multicolumn{1}{c}{ Aspek } & Skor Presentase \\
\hline Kesesuaian Penggunaan Bahasa & $95 \%$ \\
\hline Keterbacaan Media & $100 \%$ \\
\hline \multicolumn{1}{c}{ Rata-Rata Skor } & $97,5 \%$ \\
\hline
\end{tabular}

Berdasarkan tabel 3 di atas, dapat dilihat bahwa produk konten e-learning oleh anggota peneliti satu mendapatkan hasil sebesar 100\% oleh ahli bahasa maka dapat dikategorikan sangat baik. Berdasarkan tabel 4 di atas, dapat dilihat bahwa produk konten e-learning website wordpress oleh anggota peneliti dua mendapatkan hasil sebesar $97,5 \%$ oleh ahli bahasa maka dapat dikategorikan sangat baik. Sedangkan hasil penilaian ahli media tersaji pada tabel 5 dan 6 .

Tabel 5. Hasil Rekapitulasi Ahli Media Anggota Peneliti Satu

\begin{tabular}{lc}
\hline \multicolumn{1}{c}{ Aspek } & Skor Presentase \\
\hline Visual & $96,88 \%$ \\
\hline Kualitas Teknik & $100 \%$ \\
\hline Panduan atau Arahan Penggunaan & $100 \%$ \\
\hline Tipografi $\quad$ Rata-Rata Skor & $100 \%$ \\
\hline \multicolumn{2}{c}{$98,21 \%$} \\
\hline
\end{tabular}


5441 Pengembangan Konten E-Learning Motion Graphic dan Website Wordpress pada Pembelajaran Warga di Sekolah Dasar - Otib Satibi Hidayat

DOI: https://doi.org/10.31004/basicedu.v5i6.1668

Tabel 6. Hasil Rekapitulasi Ahli Media Anggota Peneliti Dua

\begin{tabular}{|c|c|}
\hline Aspek & Skor Presentase \\
\hline Usability & $100 \%$ \\
\hline Sistem Navigasi & $100 \%$ \\
\hline Desain Visual & $95 \%$ \\
\hline Konten & $100 \%$ \\
\hline Compatibility & $100 \%$ \\
\hline Loading Time & $100 \%$ \\
\hline Accesbility & $100 \%$ \\
\hline Interactivity & $95 \%$ \\
\hline
\end{tabular}

Berdasarkan tabel $5 \mathrm{di}$ atas, dapat dilihat bahwa produk konten e-learning motion graphics oleh anggota satu mendapatkan hasil sebesar $98,21 \%$ oleh ahli media maka dapat dikategorikan sangat baik. Berdasarkan tabel 6 di atas, dapat dilihat bahwa produk konten e-learning website wordpress oleh anggota dua mendapatkan hasil sebesar 97,3\% oleh ahli media maka dapat dikategorikan sangat baik.

Setelah dilakukan validasi produk oleh para ahli, tahapan selanjutnya adalah uji coba kepada peserta didik. Adapun hasil one-to-one trying out yang dilakukan oleh 1 orang guru dan 4 orang siswa oleh anggota peneliti satu serta 3 orang siswa oleh anggota peneliti dua, diperoleh hasil rekapitulasi kuesioner tersaji pada tabel 7 dan tabel 8 .

Tabel 7. Hasil Rekapitulasi uji coba one-to-one Anggota Peneliti Satu

\begin{tabular}{cccc}
\hline No & Responden & Jumlah & Presentase (\%) \\
\hline 1 & SDS (guru) & 10 & $100 \%$ \\
\hline 2 & L & 10 & $90 \%$ \\
\hline 3 & RMP & 10 & $87,5 \%$ \\
\hline 4 & N & 10 & $77,5 \%$ \\
\hline 5 & NAO & 10 & $92,5 \%$ \\
\hline & Rata-rata & 50 & $89,5 \%$ \\
\hline
\end{tabular}

Tabel 8. Hasil Rekapitulasi uji coba one-to-one Anggota Peneliti Dua

\begin{tabular}{cccc}
\hline No & Responden & Jumlah & Presentase (\%) \\
\hline 1 & DDAH & 10 & $94 \%$ \\
\hline 2 & NNMA & 10 & $96 \%$ \\
\hline 3 & BRA & 10 & $98 \%$ \\
\hline & Rata-rata & 30 & $96 \%$ \\
\hline
\end{tabular}

Berdasarkan tabel $7 \mathrm{di}$ atas, dapat dilihat bahwa konten e-learning motion graphics oleh anggota peneliti satu mendapatkan rata-rata presentase penilaian pada tahap one-to-one sebesar $89,5 \%$ yang artinya sangat baik. Berdasarkan tabel $8 \mathrm{di}$ atas, dapat dilihat bahwa konten e-learning website wordpress oleh anggota peneliti dua mendapatkan presentase penilaian pada tahap one-to-one sebesar $96 \%$ yang artinya sangat baik.

Salah satu nilai karakter yang dipelajari dalam pembelajaran PPKn SD adalah menekankan dalam pembentukan sikap, moral, dan karakter. Sikap, moral, dan karakter tersebut perlu ditanamkan kepada semua peserta didik sejak dini melalui pembelajaran yang efektif dan menyenangkan. Pembelajaran yang menyenangkan memang sangat cocok untuk diterapkan dalam pembelajaran PPKn SD. Menggunakan konten e-learning berbasis motion graphic dan website wordpress dapat dikatakan hal yang menyenangkan bagi usia anak-anak sekolah dasar (Forgó, 2013; Önal \& Alemdağ, 2018; Pati \& Majhi, 2019; Stančin et al., 2020). 
5442 Pengembangan Konten E-Learning Motion Graphic dan Website Wordpress pada Pembelajaran Warga di Sekolah Dasar - Otib Satibi Hidayat

DOI: https://doi.org/10.31004/basicedu.v5i6.1668

Nama produk dibuat semudah mungkin untuk memudahkan peserta didik dan pendidik lebih cepat dan mudah dalam mengingatnya. Sesuai dengan pendapat Gunawan, bahwa formula dalam membuat merek adalah; mudah diingat, mengandung makna, familiar, unik, serta baru. Salah satu keuntungan dari pemakaian nama produk yang mudah diingat yaitu membuat konsumen setia dalam memakainya. (A. Gunawan R. Chakti, 2019).

Menggunakan dan melibatkan diri antar siswa dalam belajar melalui e-learning tersebut akan membuat mereka senang dan akan terbawa arus dari misi yang tertulis dalam konten tersebut. Dalam hal ini guru dapat memanfaatkan konten e-learning berbasis motion graphic dan website wordpress untuk meningkatkan pembentukan moral. Di sinilah pentingnya penelitian tentang peningkatan pembentukan moral siswa padapembelajaran PPKn SD dengan konten e-learning berbasis motion graphic dan website.

Peneliti mengembangkan website ini yang dibantu dengan CMS yaitu wordpress yang akan memudahkan peneliti dalam membangun website lebih menarik, serta penggunaan plugin untuk membantu membangun website. Tampilan utama akan menampilkan banyak fitur, siswa dapat memilih akan mempelajari menggunakan fitur apa. Website ini memuat satu tema saja, yaitu tema 4 Sehat Itu Penting. Pada tema Sehat Itu Penting terdapat 3 Sub tema yang terdiri dari: a. Sub tema 1 Peredaran Darahku Sehat, b. Sub tema 2 Gangguan Kesehatan Pada Organ Peredaran Darah, c. Sub tema 3 Cara Memelihara Kesehatan Organ Peredaran Darah Manusia. Setiap sub tema memiliki 6 pembelajaran, dalam tema Sehat Itu Penting materi PPKn akan mengajak peserta didik untuk mempelajari hak dan kewajiban dalam warga masyarakat dan lingkungan sekitar (Hasanah et al., 2021; Hasanah, Marini, et al., 2020).

Produk ini sangat bermanfaat bagi guru, siswa,, dan orang tua. Di samping berperan sebagai media belajar, adanya konten e-learning berbasis web juga dapat memfasilitasi komunikasi siswa dengan teman sebayanya dan memudahkan guru memberikan tindak lanjut terhadap siswanya. Aktivitas yang diberikan guru juga tidak monoton hanya pemberian tugas melainkan dapat berupa kasus, tugas wawancara, proyek dan aktivitas inquiry menarik lainnya (Fahrurrozi et al., 2019; Hasanah, Edwita, et al., 2020).

\section{KESIMPULAN}

Peneliti melakukan penelitian dan pengembangan dengan menghasilkan sebuah produk yaitu Pengembangan Konten E-learning (Motion graphics dan Website Wordpress) dalam Pembelajaran PPKn Kelas V Sekolah Dasar dalam tema 4 "Sehat Itu Penting". Pengembangan oleh anggota peneliti satu ini mengacu pada model ADDIE terdiri dari 5 langkah yaitu analyze, development, implementation, and evaluation. Penelitian diawali dengan analisis kebutuhan, setelah itu peneliti melakukan perencanaan yang akan dieksekusi pada tahap pengembangan. Validasi dilakukan oleh tiga orang ahli yaitu satu ahli materi, satu ahli media, dan satu ahli bahasa. Validasi yang dilakukan oleh ahli materi mendapat rata-rata 83,33\%, ahli media mendapat rata-rata $98,21 \%$ dan ahli bahasa mendapat rata-rata $100 \%$. Sedangkan uji coba one to one mendapat hasil $89,5 \%$. Berdasarkan validasi ahli materi, ahli media, dan ahli bahasa, dapat diketahui hasil validasi ahli materi sebesar $94 \%$ atau sangat baik, ahli media 97,3\% atau sangat baik, dan ahli bahasa 87,5\% atau sangat baik. Sedangkan hasil uji coba One to One didapatkan hasil $96 \%$ atau sangat baik.

\section{DAFTAR PUSTAKA}

Bhamani, S., Makhdoom, A. Z., Bharuchi, V., Ali, N., Kaleem, S., \& Ahmed, D. (2020). Home Learning In Times Of COVID: Experiences Of Parents. Journal Of Education And Educational Development, 7(1), 9. Https://Doi.Org/10.22555/Joeed.V7i1.3260

Das, K., Gryseels, M., Sudhir, P., \& Tan, K. T. (2016). Unlocking Indonesia’s Digital Opportunity. Mckinsey $\&$

Company,

October,

$1-28$. 
5443 Pengembangan Konten E-Learning Motion Graphic dan Website Wordpress pada Pembelajaran Warga di Sekolah Dasar - Otib Satibi Hidayat

DOI: https://doi.org/10.31004/basicedu.v5i6.1668

Https://Www.Mckinsey.Com/ /Media/Mckinsey/Locations/Asia/Indonesia/Our Indonesias Digital Opportunity/Unlocking_Indonesias_Digital_Opportunity.Ashx

Insights/Unlocking

Dhawan, S. (2020). Online Learning: A Panacea In The Time Of COVID-19 Crisis. Journal Of Educational Technology Systems, 49(1), 5-22. Https://Doi.Org/10.1177/0047239520934018

Djamas, D., Tinedi, V., \& Yohandri. (2018). Development Of Interactive Multimedia Learning Materials For Improving Critical Thinking Skills. International Journal Of Information And Communication Technology Education, 14(4), 66-84. Https://Doi.Org/10.4018/IJICTE.2018100105

Fahrurrozi, Hasanah, U., \& Dewi, R. S. (2019). Integrated Learning Design Based On Google Classroom To Improve Student Digital Literacy. 2019 5th International Conference On Education And Technology, ICET 2019, 108-111. Https://Doi.Org/10.1109/ICET48172.2019.8987219

Fahrurrozi, Hasanah, U., Dewi, R. S., \& Ratnaningsih, S. (2020). Effectiveness Of Digital Teaching Materials Based On Google Classroom To Improve Digital Literacy Competencies During The COVID-19 Pandemic Period. Proceedings - 2020 6th International Conference On Education And Technology, ICET 2020, 59-63. Https://Doi.Org/10.1109/ICET51153.2020.9276590

Forgó, S. (2013). New Media, New Media Literacy, New Methods In Education. Proceedings Of The 2013 IEEE 63rd Annual Conference International Council For Education Media, ICEM 2013. Https://Doi.Org/10.1109/CICEM.2013.6820148

Hasanah, U., Edwita, \& Januar, A. (2020). Pelatihan Pengembangan Digital Assesment Bagi Guru Sekolah Dasar Di Kepulauan Seribu. BERNAS: Jurnal Pengabdian Kepada Masyarakat, 1(4), 338-346. Https://Doi.Org/10.31949/Jb.V1i4.448

Hasanah, U., Marini, A., \& Maksum, A. (2021). Multicultural Education-Oriented Digital Teaching Materials To Improve Students' Pluralist Attitudes. Jurnal Prima Edukasia, 9(1), 118-126. Https://Doi.Org/10.21831/Jpe.V9i1.35503

Hasanah, U., Marini, A., \& Wahyudi, A. (2020). The Utilization Of Flashcard On Elementary School Student Healthy Lifestyle In Jakarta. Jour Of Adv Research In Dynamical \& Control Systems, 12(06), 32583263. Https://Doi.Org/10.5373/JARDCS/V12I6/S20201294

Karwati, E. (N.D.). Pengaruh Pembelajaran Elektronik (E-Learning) Terhadap Mutu Belajar Mahasiswa The Influence Of E-Learning Based On Information Technology Toward Students Quality Of Learning.

Mahyoob, M. (2020). Challenges Of E-Learning During The COVID-19 Pandemic Experienced By EFL Learners. Arab World English Journal, 11(4), 351-362. Https://Doi.Org/10.24093/Awej/Vol11 no4.23

Makhaya, B. K., \& Ogange, B. O. (2019). The Effects Of Institutional Support Factors On Lecturer Adoption Of Elearning At A Conventional University. Journal Of Learning For Development, 6(1), 64-75.

Maudiarti, S. (2018). Penerapan E-Learning Di Perguruan Tinggi Santi Maudiarti Sekolah Tinggi Pariwisata Trisakti. Perspektif Ilmu Pendidikan, 32(1), 53-68.

Mocanu, I., \& Schipor, O. A. (2017). A Serious Game For Improving Elderly Mobility Based On User Emotional State. Elearning \& Software For Education.

Modlinger, D. (2020). Elearning Und Mobile Learning - Konzept Und Drehbuch. Http://Books.Google.Com/Books?Id=7gk0ksbevyac\&Pgis=1\%5Cnhttp://Link.Springer.Com/10.1007/97 8-3-642-17206-9\%5Cnhttp://Link.Springer.Com/10.1007/978-3-642-17206-9

Önal, N., \& Alemdağ, E. (2018). Educational Website Design Process: Changes In TPACK Competencies And Experiences. International Journal of Progressive Education, 14(1), 88-104. Https://Doi.Org/10.29329/Ijpe.2018.129.7

Pangalila, T. (2017). Peningkatan Civic Disposition Siswa Melalui Pembelajaran Pendidikan Kewarganegaraan (Pkn). 7, 91-103.

Pati, B., \& Majhi, S. (2019). Information Literacy Skill. International Journal Of Digital Literacy And Digital 
5444 Pengembangan Konten E-Learning Motion Graphic dan Website Wordpress pada Pembelajaran Warga di Sekolah Dasar - Otib Satibi Hidayat

DOI: https://doi.org/10.31004/basicedu.v5i6.1668

Competence, 10(1), 15-33. Https://Doi.Org/10.4018/Ijdldc.2019010102

Sadikin, A., Hamidah, A., Studi, P., Biologi, P., Universitas, F., Kampus, J., Masak, P., Jambi, J., Bulian, M., Indah, M., Jaluko, K., Muarojambi-, K., Kode, J., \& Artikel, I. (N.D.). BIODIK: Jurnal Ilmiah Pendidikan Biologi Pembelajaran Daring Di Tengah Wabah Covid-19. Https://Doi.Org/10.22437/Bio.V6i2.9759

Saputra, A. B. (2018). Pembuatan Motion Graphic Sebagai Media Promosi Untuk Proyek Datsun Sigap: Kopertip: Jurnal Ilmiah Manajemen Informatika Dan Komputer, 2(2), 84-97. Https://Doi.Org/10.32485/KOPERTIP.V2I2.51

Segeč, P. (2015). The Integration Of Webrtc And SIP: Way Of Enhancing Real-Time, Interactive Multimedia Communication. In ICETA 2014 - 12th IEEE International Conference On Emerging Elearning Technologies And Applications, Proceedings (Pp. 437-442). Https://Doi.Org/10.1109/ICETA.2014.7107624

Stančin, K., Hoić-Božić, N., \& Skočić Mihić, S. (2020). Using Digital Game-Based Learning For Students With Intellectual Disabilities - A Systematic Literature Review. Informatics In Education, 19(2), 323341. Https://Doi.Org/10.15388/INFEDU.2020.15

Trimarsiah, Y., \& Arafat, M. (2017). Analisis Dan Perancangan Website Sebagai Sarana Informasi Pada Lembaga Bahasa Kewirausahaan Dan Komputer Akmi Baturaja Menggunakan Php Dan Mysql. Jurnal Ilmiah Matrik, 19(1), 1-10. Https://Doi.Org/10.33557/Jurnalmatrik.V19I1.366

Widodo, A., Nursaptini, N., Novitasari, S., Sutisna, D., \& Umar, U. (2020). From Face-To-Face Learning To Web Base Learning: How Are Student Readiness? Premiere Educandum: Jurnal Pendidikan Dasar Dan Pembelajaran, 10(2), 149. Https://Doi.Org/10.25273/Pe.V10i2.6801

Wu, T. J., \& Tai, Y. N. (2016). Effects Of Multimedia Information Technology Integrated Multi-Sensory Instruction On Students' Learning Motivation And Outcome. Eurasia Journal Of Mathematics, Science And Technology Education, 12(4), 1065-1074. Https://Doi.Org/10.12973/Eurasia.2016.1552a

Zinnurain, \& Gafur, A. (2015). Jurnal Inovasi Teknologi Pendidikan. Jurnal Inovasi Teknologi Pendidikan, 2(2), 157-168. 